\title{
Serum Fructosamine in Neonate
}

\author{
Somsri Wiwanitkit • Viroj Wiwanitkit
}

Received: 9 July 2011 / Accepted: 1 December 2011 /Published online: 20 December 2011

(C) Dr. K C Chaudhuri Foundation 2011

Sir,

The recent publication on serum fructosamine and retinopathy is very interesting [1]. It is concluded that "serum corrected fructosamine does not have a good predictive value in developing retinopathy of prematurity in verylow-birth-weight (VLBW) infants [1]." A concern is on the measurement of serum fructosamine in this work. Indeed, the cord blood measurement of serum fructosamine seems to be a useless investigation since the actual usefulness of serum fructosamine is for tracing back of the previous practice on glucose consumption and control which is totally not possible for the newborn. Although it is accepted that fructosamine formation might lead to cellular pathology [2], the existence of feto-maternal circulation in fetus in-utero might lead to the useless determination of cord blood fructosamine level to predict any pathological problem specific to the fetus and newborn.

\section{References}

1. Bozdag S, Oguz SS, Gokmen T, et al. Serum Fructosamine and Retinopathy of Prematurity.Indian J Pediatr. 2011 Jul 6. [Epub ahead of print]; doi:10.1007/s12098-011-0515-9.

2. Wiwanitkit V. Formation of fructosamine in diabetic patients: what are implications in term of energy exchange? Diabetologia Croat. $2006 ; 35: 35-7$.

S. Wiwanitkit $(\square) \cdot$ V. Wiwanitkit

Wiwanitkit House, Bangkhae,

Bangkok, Thailand 10160

e-mail: somsriwiwan@hotmail.com

\section{Author's Reply}

Sir,

The first values of fructosamine in the cord blood of newborns were investigated to evaluate the trend of fructosamine levels (rate of expected increase in hyperglycemic infants) in comparison to subsequent levels rather than any pathologic correlation between the fetus and feto-maternal circulation as the author suggested $[1,2]$. Initially, it was hypothesized that if the neonates were exposed to hyperglycemia in the first two wk of life, this situation would be supported by an increased levels of serum fructosamine in subsequent 2-3 wk. Therefore, there was a need for determining initial values of serum fructosamine at birth to compare it with the subsequent values of serum fructosamine on follow up. We suggested that it is important to know whether serum fructosamine level correlated with hyperglycemia or not during the hospitalization period.

\author{
S. Bozdag $\cdot$ S. S. Oguz $\cdot$ T. Gokmen $\cdot$ O. Erdeve $\cdot$ U. Dilmen \\ Department of Neonatology, \\ Zekai Tahir Burak Maternity and Teaching Hospital, Ankara, Turkey \\ S. Bozdag $(\bowtie)$ \\ Bengü çıkmazi sk. No: 3/19 Erenköy, Istanbul, Turkey \\ e-mail: senolbozdag@hotmail.com
}

\section{References}

1. Bozdag S, Oguz SS, Gokmen T, Tunay Z, Tok L, Uras N, Erdeve O, Dilmen U. Serum Fructosamine and Retinopathy of Prematurity. Indian J Pediatr. 2011 Jul 6. [Epub ahead of print]; doi:10.1007/ s12098-011-0515-9

2. Wiwanitkit V. Formation of fructosamine in diabetic patients: what are implications in term of energy change? Diabetologia Croat. 2006;35:35 - 7 . 